\title{
A General Strategy to Convert the MerR Family Proteins into Highly Sensitive and Selective Fluorescent Biosensors for Metal ions \\ Peng Chen and Chuan $\mathrm{He}^{*}$ \\ Department of Chemistry, The University of Chicago, 5735 S. Ellis Avenue, Chicago, IL 60637 \\ Received xx xx, 2003; E-mail: chuanhe@uchicago.edu
}

\section{Supporting Information}

\section{Construction, Expression and Purification of Wild-Type E. coli CueR and MerR.}

The E.coli CueR gene was cloned into HindIII and NdeI sites of PET30a vector (Novagen) and transformed with E.Coli BL21(DE3) onto LB-agar plates containing kanamycin $(50 \mu \mathrm{M})$. Overnight pre-cultures were grown aerobically at $37{ }^{\circ} \mathrm{C}$ and shaken at $200 \mathrm{rpm}$, which was then used to inoculate $1 \mathrm{~L}$ of LB medium and kanamycin $(50 \mu \mathrm{M})$. The cells were grown until the $\mathrm{OD}_{600}$ was 0.6 . IPTG $(1 \mathrm{mM})$ were added and the cells were grown for an additional $4 \mathrm{~h}$ at $37{ }^{\circ} \mathrm{C}$. The cells were harvested by centrifugation and stored at $-80{ }^{\circ} \mathrm{C}$. All subsequent steps were performed at $4{ }^{\circ} \mathrm{C}$. The cell pellet was resuspended in $30 \mathrm{ml}$ of lysis buffer $(10 \mathrm{mM}$ Tris [pH 7.34], 300 $\mathrm{mM} \mathrm{NaCl}, 10 \mathrm{mM}$ 2-mercaptoethanol), disintegrated by sonication, and centrifuged at $12000 \mathrm{rpm}$ for 20 minutes. The protein in the supernatant was then purified by following the published procedure. ${ }^{1}$ Previously published procedure to express and purify the E. coli MerR protein was also followed to obtain the His ${ }_{6}$-tagged MerR protein. $^{2}$

Synthetic Oligonucleotides. Oligodeoxynucleotides were synthesized on an Applied Biosystems 392 DNA synthesizer. The pyrrolo-C-containing oligonucleotides were prepared by incorporation of Pyrrolo-C-CE phosphoramidite (Glen Research) at the modified positions during solid-phase synthesis, followed by deprotection and purification by denaturing polyacrylamide gel electrophoresis. Concentrations of the oligonucleotides were estimated by UV at $260 \mathrm{~nm}$.

Fluorescent sensory of metal ions by the biosensor. The fluorescent measurements were performed at $15{ }^{\circ} \mathrm{C}$ with the use of a FluoroMax-3 (JOBIN YVON Inc.) and 
excited at $350 \mathrm{~nm}$. Metal ions were added to the DNA probe with the purified E. coli CueR protein in a nitrogen-purged buffer containing $10 \mathrm{mM}$ Tris- $\mathrm{HCl}$ (pH 7.34), 100 $\mathrm{mM} \mathrm{NaCl}$ and reducing agent (1 $\mathrm{mM}$ dithiothreitol: DTT for copper(I), $5 \mathrm{mM}$ Tris(2-carboxyethyl) phosphine: TCEP for silver(I) and other metal ions). $\mathrm{NaNO}_{3}$ was used in the place of $\mathrm{NaCl}$ for the study of silver(I) binding. The study of the MerR-based sensor was performed in a nitrogen-purged buffer containing $10 \mathrm{mM}$ Tris- $\mathrm{HCl}(\mathrm{pH} 7.34), 100 \mathrm{mM}$ potassium glutamate, $2 \mathrm{mM} \mathrm{MgCl} 2,5 \%$ glycerol and 1 mM DTT to ensure that the MerR protein would be stable under these conditions.

\section{References:}

(1) Outten, F. W.; Outten, C. E.; Hale, J.; O'Halloran, T. V. J. Biol. Chem. 2000, 275, 31024-31029.

(2) Zeng, Q. D.; Stalhandske, C.; Anderson, M. C.; Scott, R. A.; Summers, A. O. Biochemistry 1998, 37, 15885-15895. 
A

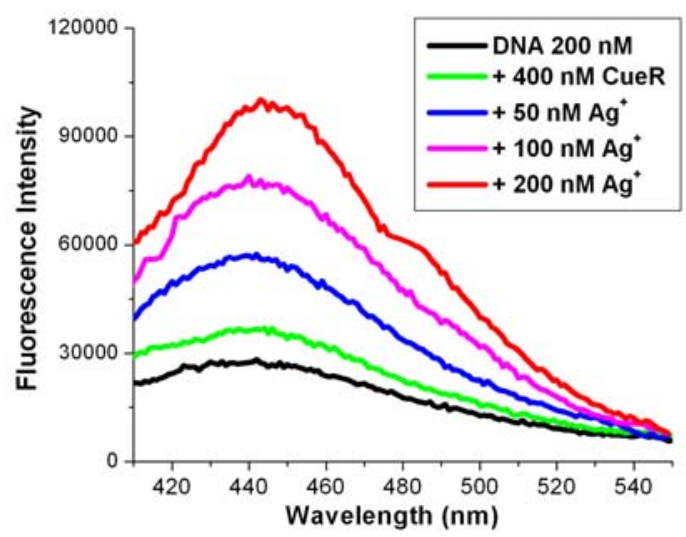

B

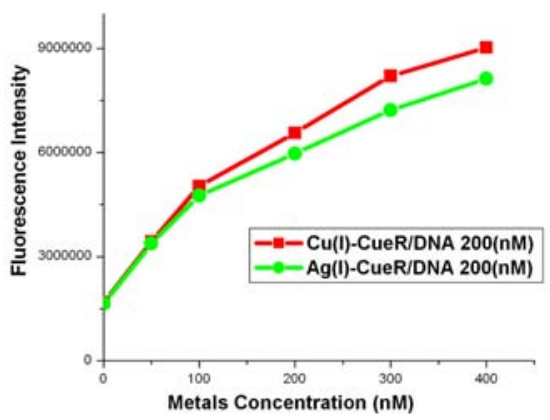

Figure S1. (A) Fluorescence spectra of the E. coli CueR-based biosensor in the absence and presence of various amounts of $\mathrm{Ag}^{+}$ion (with $10 \mathrm{mM}$ Tris [pH 7.4], $100 \mathrm{mM}$ $\mathrm{NaNO}_{3}$ and $5 \mathrm{mM}$ of TCEP). (B) Metal-binding curves for response of CueR towards $\mathrm{Cu}^{+}$and $\mathrm{Ag}^{+}$(the intensity was integrated from $410 \mathrm{~nm}$ to $550 \mathrm{~nm}$ ).

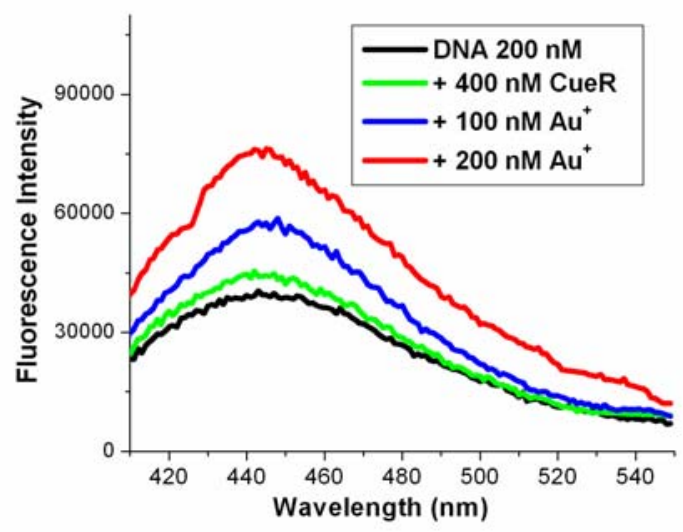

Figure S2. Fluorescence spectra of the E. coli CueR-based biosensor in the absence and presence of $\mathrm{Au}^{+}$ion (with $10 \mathrm{mM}$ Tris [pH 7.4], $100 \mathrm{mM} \mathrm{NaCl}$ and $5 \mathrm{mM}$ of TCEP). 


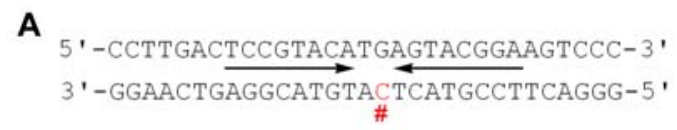

Fluorescent DNA probe for the $E$. coli MerR protein

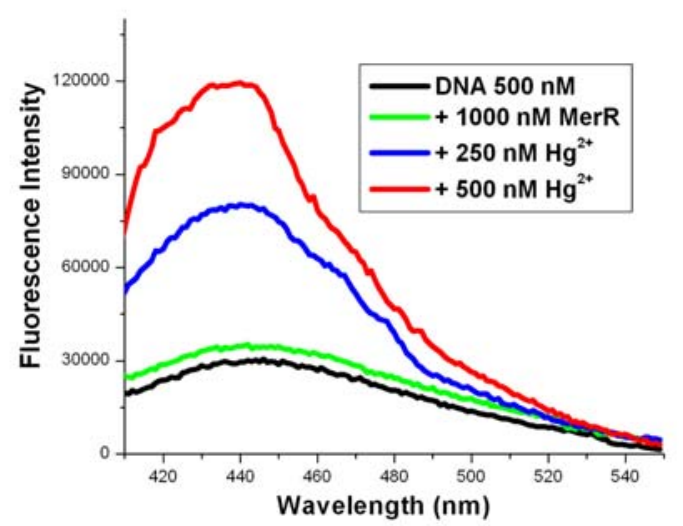

B

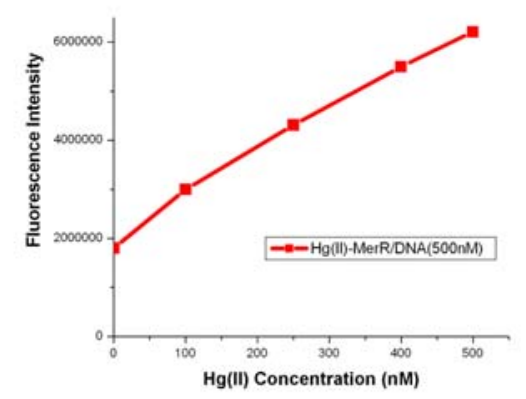

Figure S3. (A) Fluorescence responses of the E. coli MerR-based biosensor toward $\mathrm{Hg}^{2+}$ ion. The sequence of the DNA probe with the dyad symmetric sequence marked by arrows, and fluorescence spectra of the E. coli MerR-based biosensor in the absence and presence of $\mathrm{Hg}^{2+}$ ion (with $10 \mathrm{mM}$ Tris [pH 7.4], $100 \mathrm{mM}$ potassium glutamate, 2 $\mathrm{mM} \mathrm{MgCl} 2,5 \%$ glycerol and $1 \mathrm{mM}$ of DTT). (B) $\mathrm{Hg}$ (II)-binding curve of MerR (the intensity was integrated from $410 \mathrm{~nm}$ to $550 \mathrm{~nm}$ ). 